\title{
Russell Duncan: \\ Re-tracing history
}

Emma Jameson

Keywords: \#New Zealand \#early European explorers \#photographic albums \#photographic practice \#Captain Cook \#photography and temporality

This article considers the construction and meaning of time in Russell Duncan's photographs. A hobbyist photographer and passionate historian, Duncan extensively photographed sites associated with early European explorers and colonial history in New Zealand, focussing primarily on those associated with Captain Cook. This article analyses, for the first time, Duncan's use of the sequential format of photographic albums to manipulate timelines in order to visually reconstruct historical narratives. By analysing Duncan's photographs of sites associated with Captain Cook in detail, this article investigates how Duncan's photographs, read both individually and in a sequence, fuse past and present in their re-tracing of history. 
A co-founder of the merchant firm Ellison \& Duncan Ltd in Port Ahuriri, Napier (established in 1885), Russell Duncan's photographic practice was first and foremost a hobby, a personal pastime intertwining his passion for history and travel and the documentation of these pursuits. His enthusiasm for taking photographs is evidenced by the sheer number of albums featuring photographs taken and compiled by himself that exist in public institutions around New Zealand: one album at the Auckland Art Gallery Toi o Tāmaki; ten in the MTG Hawkes Bay Tai Ahuriri (Museum Theatre Gallery); three in the Auckland War Memorial Museum Tāmaki Paenga Hira; and seven in the Alexander Turnbull Library. Duncan also collected photographs taken by practitioners operating in New Zealand: one album in the MTG Hawkes Bay collection contains an assortment of photographic portraits taken by Samuel Carnell and other unnamed practitioners. ${ }^{1}$ Duncan was motivated purely by personal interest and not by commercial intention: there are neither advertisements listing the sale of his photographs in newspapers nor adhesive labels or stamps present in the albums suggesting they were listed for sale through a vendor. Labels inside the albums indicate that he patronized Walter Suckling Limited, based in Auckland and Christchurch, to develop or print his photographs.

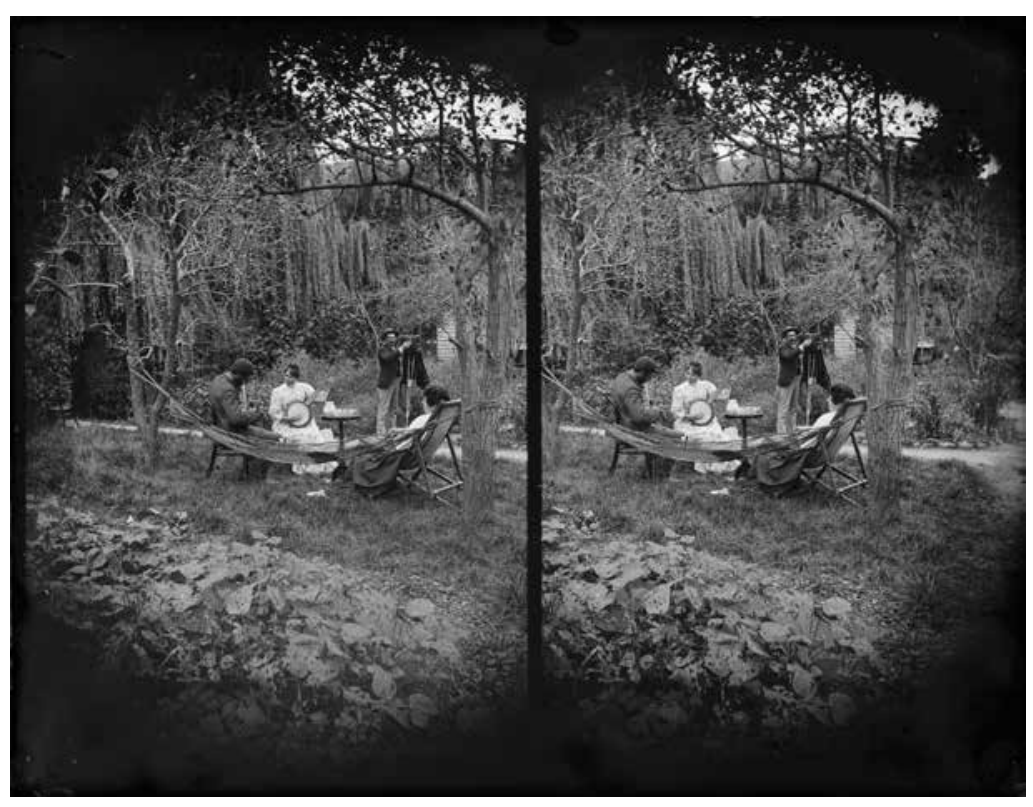

Group in the garden of William and Lydia Williams, Carlyle Street, Napier, circa 1890. Ref: T/1-025684-G. Alexander Turnbull Library. The man with the camera is Russell Duncan.
Very little has been written about Duncan's photographic practice. Kynan Gentry briefly describes his photographs in her discussion of the increased colonial interest in Captain Cook at the turn of the twentieth century. ${ }^{2}$ Photographer Mark Adams has briefly alluded to the influence of Duncan's photographs on his own practice. ${ }^{3}$ No further descriptions of Duncan's photographs exist. This article is therefore the first thorough investigation of Duncan's photographic output.

A prolific, intrepid and eager traveller, Duncan primarily used photography to record the multiple excursions he undertook within and beyond New Zealand's shores: one album records the places he visited in Tonga from July to August $1899 ; 4$ another documents a trip to Tahiti that same year; a third provides a general photographic overview of voyages made to Portsmouth, Iceland, and Wairoa. ${ }^{5}$ In 1898 he ascended Mount Ruapehu equipped with "photographic apparatus" in order to "record[ing] anything noteworthy". ${ }^{6}$ Photographs were reportedly taken at an altitude of 8,515 feet. $^{7}$

Duncan's employment of photography to record expeditions was by no means unique or extraordinary. Rather, it was encompassed within a vogue for travel writing and photography that germinated and developed as part of a tourism boom in the New Zealand colony in the 1870 s and 1880 s. $^{8}$ Travel books and photographic albums enabled travellers to record their journeys and empowered 'armchair travellers' to vicariously experience 'the great unknown', generating a market for photographs of tourist sites in New Zealand.9 Photographers like the Burton Brothers, George Valentine and Charles Spencer compiled their photographs of locales into distinct series that emphasised the processes of journeying, enabling viewers to visually traverse the depicted landscapes with each turn of the album page. ${ }^{10}$

What distinguishes Duncan's 'travel photography' from that of most of his contemporaries, however, is his way of calling attention to the temporal sequence of the journeying. Whereas photographers like the Burton Brothers and George Valentine typically inscribe their photographs simply with the name of the depicted locale or persons, Duncan accompanies most photographs with a stamp or inscription that states the date on which the image was captured. These inscriptions make apparent that Duncan's ordering of photographs varied according to the subject matter and function of the photographic albums. The date inscriptions accompanying his photographs of Tonga, for example, demonstrate that the album is arranged chronologically (i.e. the photographs are organized in the order in which they were taken) for the purposes of serving as a visual 
travelogue documenting his travels." Duncan modifies this structure slightly to significant effect in the 'Taupo Road' album, which contains photographs taken in September 1896, October 1914 and April 1915.12 In this album, the date stamps clearly signal that the photographs are not organised in the order in which they were taken, but rather are arranged to convey the various locales sighted along the Napier-Taupo road, record Duncan's multiple journeys across the sites over a period of time, and demonstrate the changes that he observed in the landscape with each re-tracing. This construction of temporality is particularly notable in his photographs of Stony Creek: one, taken in September 1896 (Fig. 2), is directly opposite another view of the area taken on 10 October 1914 (Fig. 3). Duncan draws our attention to this shift in time by inscribing underneath the latter photograph, "View taken 18 years after the one on the opposite page [own emphasis added]." In so doing, Duncan shifts his focus from narrating his journey to instead emphasise the effect of time on the depicted geography.

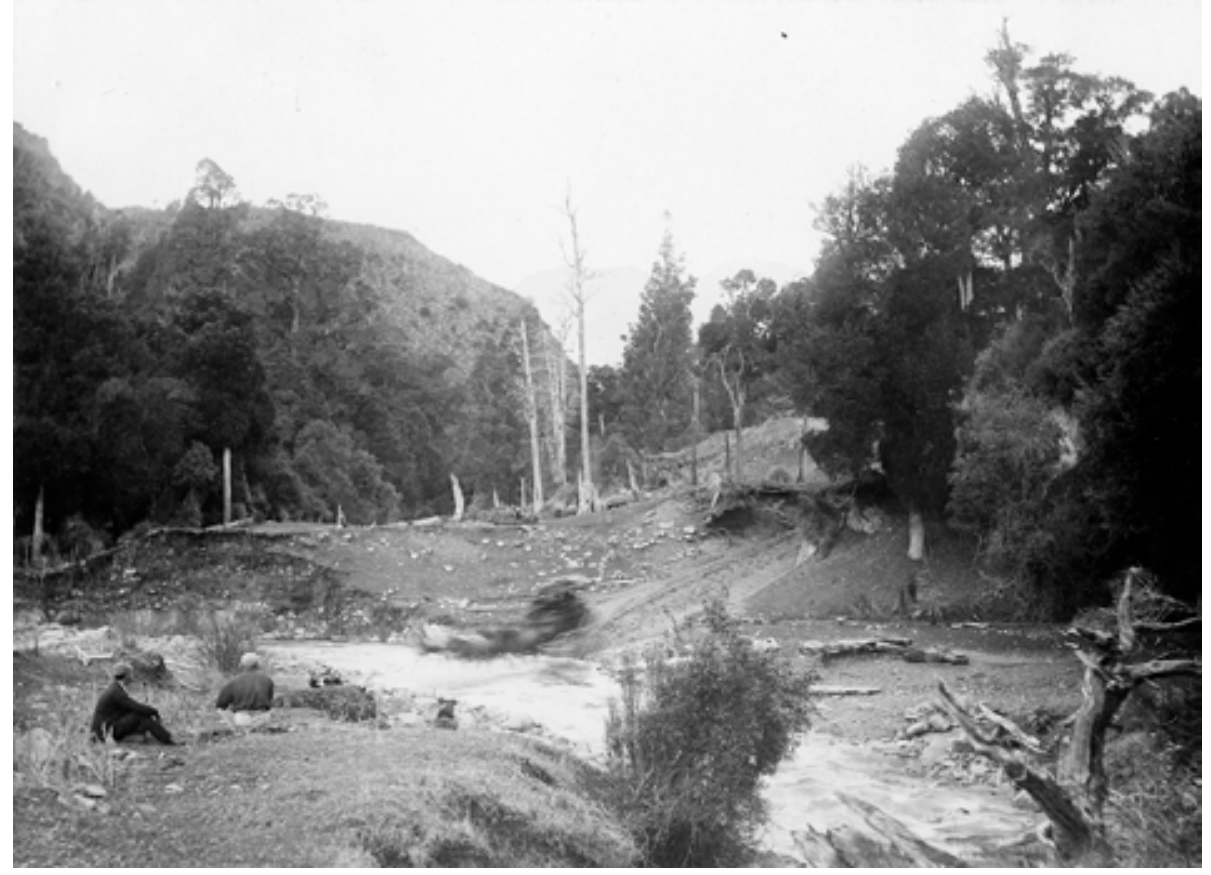

Figure 2. Russell Duncan, Napier-Taupo Road, Sept 1896, MTG Hawkes Bay, 1352, Album No 10, 73810.

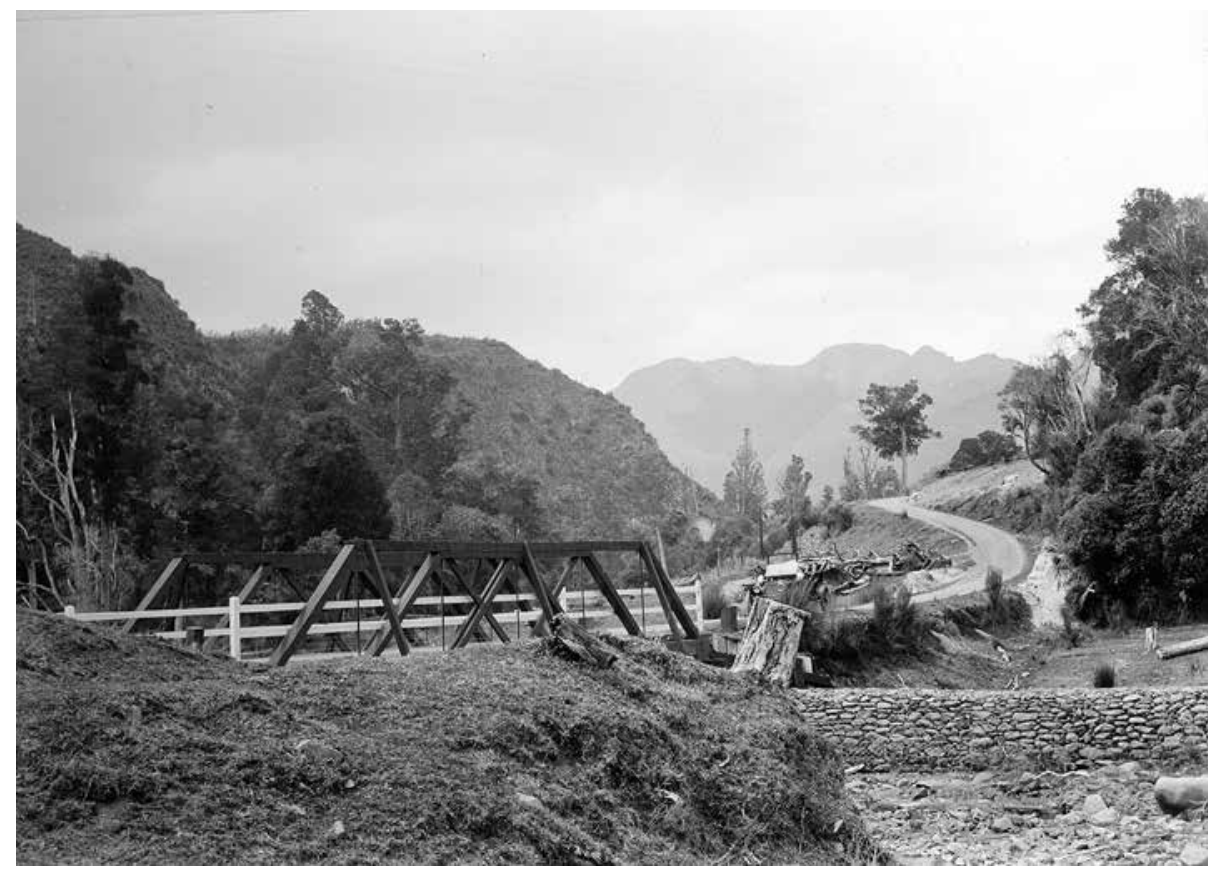

Figure 3. Russell Duncan, Napier-Taupo Road, 10 Oct 1914, MTG Hawkes Bay, 1353, Album No 10, 73856

Duncan's inscriptions overtly signal the significance of time in his organisation and in our reading of his photographic albums. The complex relationship between photography and temporality has been theorised extensively. For Walter Benjamin, "a touch of the finger... sufficed to fix an event for an unlimited period of time", condensing past and present and thus rendering the photograph and its depicted object immortal, transcendental and endless. Photography, Roland Barthes argues, occupies, "an illogical conjunction between the herenow and the there-then," a tension that results from a photograph simultaneously inferring that the depicted object remains "alive" in the present (i.e. by virtue of the fact that its simulacra still 'exists' in the photographic frame) but "by shifting this reality to the past ("this has been"), the photograph suggests that it is already dead". ${ }^{13}$ Time is not continuous or linear but is rather spatial, figurative and amorphous. ${ }^{14}$ This is more so the case when photographs are organized sequentially: the temporality of the single image is coalesced with that of others in the sequence, creating complex temporal interplays between the singular, the whole (i.e. the overall sequence), the intervals between the individual photographs and the viewing process of the beholder. ${ }^{15}$ 


\section{Russell Duncan: \\ Re-tracing history}

Emma Jameson

Keywords: \#New Zealand \#early European explorers \#photographic albums \#photographic practice \#Captain Cook \#photography and temporality

This article considers the construction and meaning of time in Russell Duncan's photographs. A hobbyist photographer and passionate historian, Duncan extensively photographed sites associated with early European explorers and colonial history in New Zealand, focussing primarily on those associated with Captain Cook. This article analyses, for the first time, Duncan's use of the sequential format of photographic albums to manipulate timelines in order to visually reconstruct historical narratives. By analysing Duncan's photographs of sites associated with Captain Cook in detail, this article investigates how Duncan's photographs, read both individually and in a sequence, fuse past and present in their re-tracing of history. 
A co-founder of the merchant firm Ellison \& Duncan Ltd in Port Ahuriri, Napier (established in 1885), Russell Duncan's photographic practice was first and foremost a hobby, a personal pastime intertwining his passion for history and travel and the documentation of these pursuits. His enthusiasm for taking photographs is evidenced by the sheer number of albums featuring photographs taken and compiled by himself that exist in public institutions around New Zealand: one album at the Auckland Art Gallery Toi o Tāmaki; ten in the MTG Hawkes Bay Tai Ahuriri (Museum Theatre Gallery); three in the Auckland War Memorial Museum Tāmaki Paenga Hira; and seven in the Alexander Turnbull Library. Duncan also collected photographs taken by practitioners operating in New Zealand: one album in the MTG Hawkes Bay collection contains an assortment of photographic portraits taken by Samuel Carnell and other unnamed practitioners. ${ }^{1}$ Duncan was motivated purely by personal interest and not by commercial intention: there are neither advertisements listing the sale of his photographs in newspapers nor adhesive labels or stamps present in the albums suggesting they were listed for sale through a vendor. Labels inside the albums indicate that he patronized Walter Suckling Limited, based in Auckland and Christchurch, to develop or print his photographs.

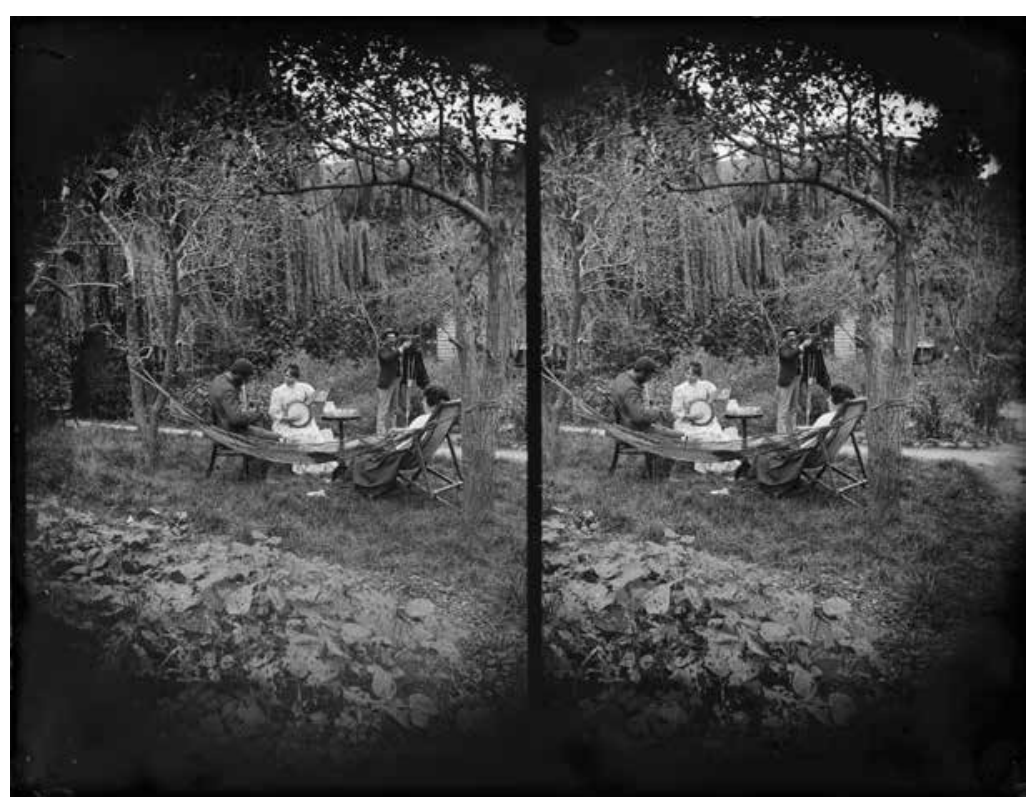

Group in the garden of William and Lydia Williams, Carlyle Street, Napier, circa 1890. Ref: T/1-025684-G. Alexander Turnbull Library. The man with the camera is Russell Duncan.
Very little has been written about Duncan's photographic practice. Kynan Gentry briefly describes his photographs in her discussion of the increased colonial interest in Captain Cook at the turn of the twentieth century. ${ }^{2}$ Photographer Mark Adams has briefly alluded to the influence of Duncan's photographs on his own practice. ${ }^{3}$ No further descriptions of Duncan's photographs exist. This article is therefore the first thorough investigation of Duncan's photographic output.

A prolific, intrepid and eager traveller, Duncan primarily used photography to record the multiple excursions he undertook within and beyond New Zealand's shores: one album records the places he visited in Tonga from July to August $1899 ; 4$ another documents a trip to Tahiti that same year; a third provides a general photographic overview of voyages made to Portsmouth, Iceland, and Wairoa. ${ }^{5}$ In 1898 he ascended Mount Ruapehu equipped with "photographic apparatus" in order to "record[ing] anything noteworthy". ${ }^{6}$ Photographs were reportedly taken at an altitude of 8,515 feet. $^{7}$

Duncan's employment of photography to record expeditions was by no means unique or extraordinary. Rather, it was encompassed within a vogue for travel writing and photography that germinated and developed as part of a tourism boom in the New Zealand colony in the 1870 s and 1880 s. $^{8}$ Travel books and photographic albums enabled travellers to record their journeys and empowered 'armchair travellers' to vicariously experience 'the great unknown', generating a market for photographs of tourist sites in New Zealand.9 Photographers like the Burton Brothers, George Valentine and Charles Spencer compiled their photographs of locales into distinct series that emphasised the processes of journeying, enabling viewers to visually traverse the depicted landscapes with each turn of the album page. ${ }^{10}$

What distinguishes Duncan's 'travel photography' from that of most of his contemporaries, however, is his way of calling attention to the temporal sequence of the journeying. Whereas photographers like the Burton Brothers and George Valentine typically inscribe their photographs simply with the name of the depicted locale or persons, Duncan accompanies most photographs with a stamp or inscription that states the date on which the image was captured. These inscriptions make apparent that Duncan's ordering of photographs varied according to the subject matter and function of the photographic albums. The date inscriptions accompanying his photographs of Tonga, for example, demonstrate that the album is arranged chronologically (i.e. the photographs are organized in the order in which they were taken) for the purposes of serving as a visual 
travelogue documenting his travels." Duncan modifies this structure slightly to significant effect in the 'Taupo Road' album, which contains photographs taken in September 1896, October 1914 and April 1915.12 In this album, the date stamps clearly signal that the photographs are not organised in the order in which they were taken, but rather are arranged to convey the various locales sighted along the Napier-Taupo road, record Duncan's multiple journeys across the sites over a period of time, and demonstrate the changes that he observed in the landscape with each re-tracing. This construction of temporality is particularly notable in his photographs of Stony Creek: one, taken in September 1896 (Fig. 2), is directly opposite another view of the area taken on 10 October 1914 (Fig. 3). Duncan draws our attention to this shift in time by inscribing underneath the latter photograph, "View taken 18 years after the one on the opposite page [own emphasis added]." In so doing, Duncan shifts his focus from narrating his journey to instead emphasise the effect of time on the depicted geography.

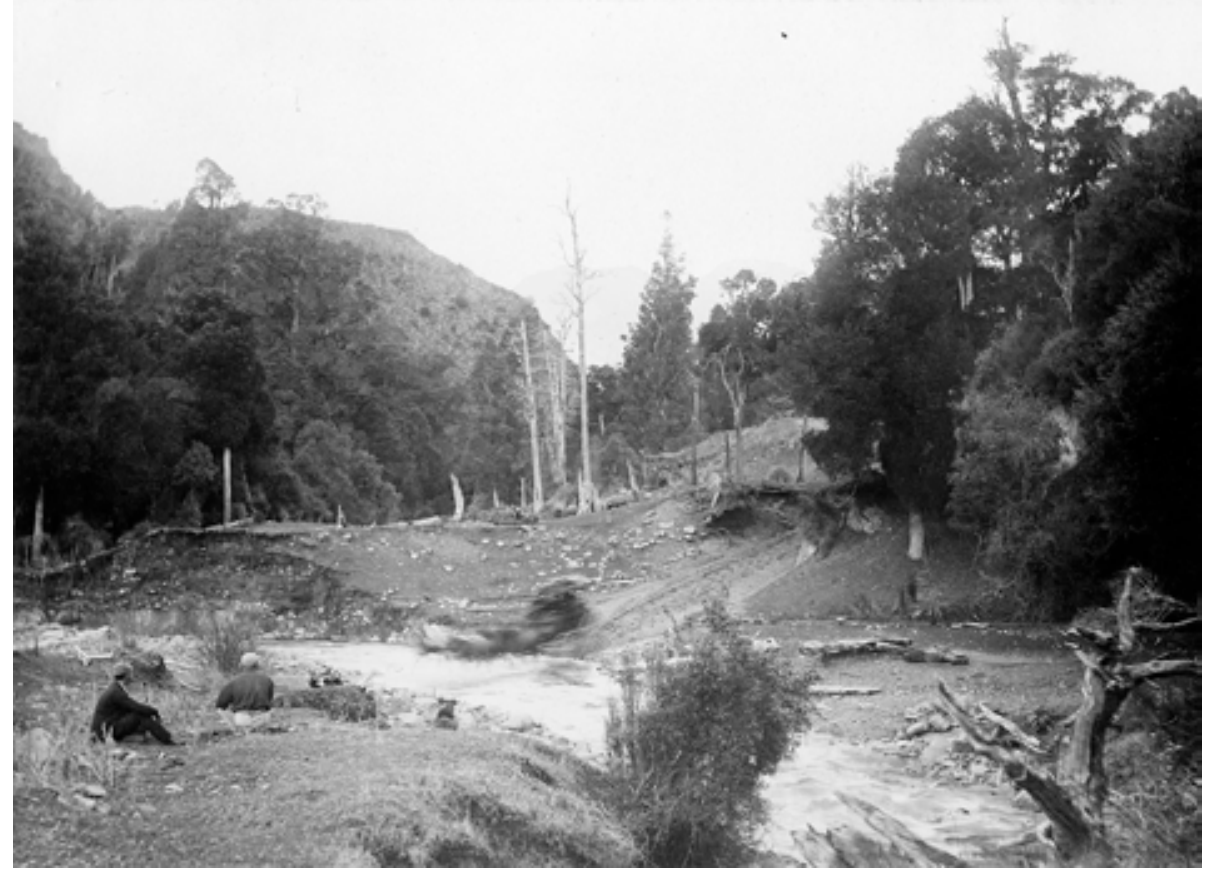

Figure 2. Russell Duncan, Napier-Taupo Road, Sept 1896, MTG Hawkes Bay, 1352, Album No 10, 73810.

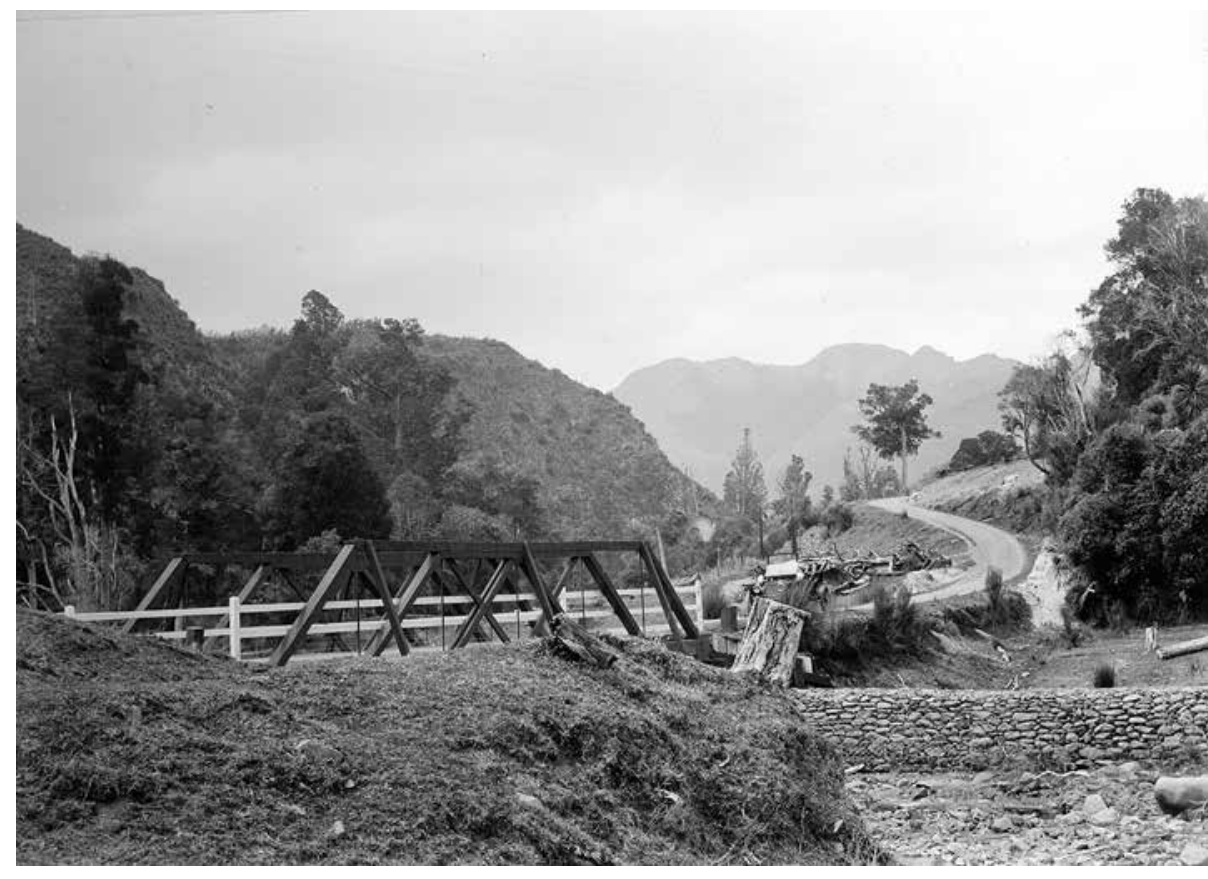

Figure 3. Russell Duncan, Napier-Taupo Road, 10 Oct 1914, MTG Hawkes Bay, 1353, Album No 10, 73856

Duncan's inscriptions overtly signal the significance of time in his organisation and in our reading of his photographic albums. The complex relationship between photography and temporality has been theorised extensively. For Walter Benjamin, "a touch of the finger... sufficed to fix an event for an unlimited period of time", condensing past and present and thus rendering the photograph and its depicted object immortal, transcendental and endless. Photography, Roland Barthes argues, occupies, "an illogical conjunction between the herenow and the there-then," a tension that results from a photograph simultaneously inferring that the depicted object remains "alive" in the present (i.e. by virtue of the fact that its simulacra still 'exists' in the photographic frame) but "by shifting this reality to the past ("this has been"), the photograph suggests that it is already dead". ${ }^{13}$ Time is not continuous or linear but is rather spatial, figurative and amorphous. ${ }^{14}$ This is more so the case when photographs are organized sequentially: the temporality of the single image is coalesced with that of others in the sequence, creating complex temporal interplays between the singular, the whole (i.e. the overall sequence), the intervals between the individual photographs and the viewing process of the beholder. ${ }^{15}$ 
The sequential nature of the photographic album format constitutes the crux of Duncan's photographic practice, both in its purpose and in its reception. It has already been demonstrated through the Taupo Road album that Duncan manipulated the sequence of photographs within albums to construct temporal narratives for different effect. It is in his albums focussing on the voyages of Captain Cook that Duncan's purposeful ordering of photographs to suggest alternative temporal narratives is most evident. With the upcoming 250th anniversary of Cook's landing at Tūranganui-a-Kiwa (Gisborne), it is pertinent to analyse how Duncan's photographs of Cook's sites germinated from his specific socio-historical context, how they in turn perpetuate certain perspectives from this context and how we, as viewers in the twentyfirst century, can approach these photographs with this awareness.

Duncan was an eager and passionate historian with a particular interest in the voyages undertaken by early European travellers in New Zealand. Duncan's fascination impelled him to travel to Tolaga Bay (1901), Queen Charlotte Sound (1902), the Bay of Islands (1903 and 1914), and Dusky Sound (1900, 1907 and February 1910). In these excursions, he followed paths traversed by Captain Cook, Marc Joseph Marion Du Fresne, and George Vancouver, armed with historical accounts of the voyages written by George Forster, Sydney Parkinson, James Burney and J.S. Polack. Captain Cook's voyages around New Zealand

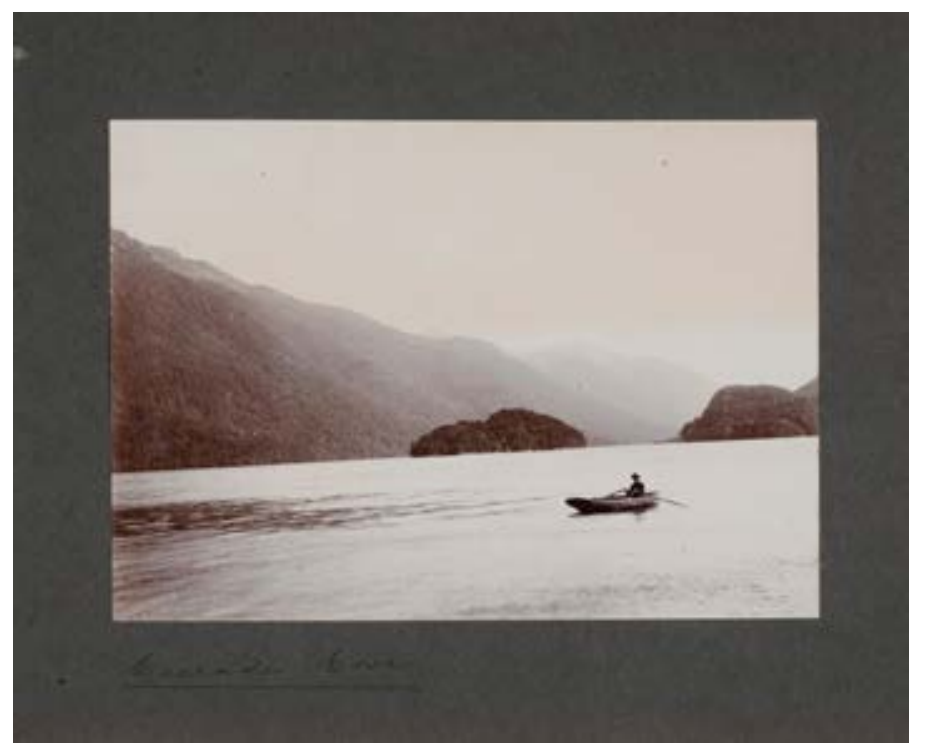

Russell Duncan, Cascade Cove circa 1905-1910, photograph (albumen print), Auckland Art 1988. The photorraph pused either Mr Walter McCarthy a geologist, or MrFG Gmith, a naturalist, both of whom a naturalist, both of whom trip to Dusky Sound. were a particular passion for Duncan, constituting the focus of the bulk of his excursions, lectures, radio interviews, personal journals and photographs. Documented with extensive observational notes and photographs, Duncan's expeditions presented him, as the Otago Daily Times observed, with an opportunity to "indulge a fascinating hobby and make a collection of historical relics and information". ${ }^{16} \mathrm{His}$ diary of his 1910 trip to the Dusky Sound describes his excitement at recovering relics from the Endeavour, both from the wreck itself and from the nearby Murray River, stating that he and his team had, "found a piece of lead about $4 \times 4$ as good as the day it was left there. ${ }^{\prime 17} \mathrm{On}$ several occasions Duncan's excursions did indeed generate historical findings: of particular note is his verification of the location of Grass Cove in Queen Charlotte Sound, where several crew members from the "Adventure" were killed on 17th December $1773 . .^{18}$ This historical research was subsequently reported in public lectures delivered at the Hawke's Bay Philosophical Institute and in at least two radio interviews conducted in 1935. ${ }^{19}$

Duncan's evident zeal at traversing historical locations was motivated by more than a desire to cross-reference, observe and gather facts; rather, the blurring of past and present through re-tracing historical footsteps seems to have been a primary motivation. Duncan describes his thrill at discovering his proximity to the exact spot of the Grass Cove massacre, stating "the feeling was rather awesome, notwithstanding [sic] the 128 years that had elapsed, the occurrence and details being vividly before our minds". ${ }^{20}$ Determined to ensure his expeditions were faithful 're-enactments' and as experientially proximate as possible, Duncan often timed his visits to coincide with the same month of the year as his historical predecessors, and proudly reported on one occasion that he had planned his attire so that he "was able to see the place much in the same garb as he [Cook] did". ${ }^{21}$ Duncan revelled in observing and postulating how the passage of time might have altered the landscape. In describing his motivations for his trip to the Queen Charlotte Sound he stated that "my object in so doing was to see for myself how these scenes compare now with the descriptions given of them by Cook and his scientific companions." ${ }^{22}$ His selfpublished book Early Walks in New Zealand (Whitcombe and Tombs, 1918), aimed to demonstrate the difference between "travel today and those early periods" through the "novel idea of following the footsteps of some of the early travellers". ${ }^{23}$ 
Duncan's interest in sites relating to colonial history was not atypical for Pākehā of his time. Such interest arose within the wider colonial context of the late nineteenth century and early twentieth century, which harnessed stories about Captain Cook and European explorers and settlers to construct a distinctly British nationalised identity in order to 'anchor' the burgeoning New Zealand colony in a continuing historical lineage. ${ }^{24}$ Duncan's interest in colonial history and his photographic practice is encompassed within national campaigns dedicated to memorialise key figures in colonial history, as part of which Captain Cook was of key focus and attention. ${ }^{25}$ In 1864 the Marlborough provincial government had set aside part of Ship Cove as a scenic reserve; by 1896 the area was landmarked as a permanent historic reserve. ${ }^{26}$

Duncan was one of several eager historians who travelled to Captain Cook's landing sites to chart his movements across the landscape. Alexander Turnbull, Robert McNab, Dr T M Hocken and H.D.M. Haszard retraced Cook's routes on land and water in order to forge an experiential nexus that could bring new understandings beyond those gleaned from journals and documents. McNab and Duncan were both advocates for the Captain Cook Memorial Committee which, from its establishment in 1902, sought to preserve Cook's memory through the erection of monuments at sites where he landed. ${ }^{27}$

Like his contemporaries, Duncan's interest in Cook was governed by a desire to faithfully retrace the explorer's steps for both historical observation and an experiential delight in blurring past and present. His photographs of Cook's sites not only visually manifest these aims but also progress them in their conscious construction of narrative. Although he was not the first avid historian to photograph Cook's sites, he is certainly the first to have done so with such persistence and in as much detail. Intended to simultaneously document the geo-historical significance of various locales; the narratives of historical voyages; the appearance of the sites; and Duncan's own expeditions, the photographs convey and embody multifarious narratives and timelines. This creates slippages between a specific history and Duncan's present, complicating the here-now and the there-then to reinforce and perpetuate colonial perspectives of the landscape.

The historical memory of Cook, as interpreted and selected by Duncan, is perpetuated and embedded onto the landscape through the photographs' descriptive and date inscriptions. The written inscriptions accompanying the photographs clearly mark the historical traces of Captain Cook that Duncan saw and sought in the landscapes he visited and depicted. In Luncheon Cove, ground level (Fig. 5), we see the site where "Capt Cook and his boats [sic] crew had their lunch by this stream on the occasion of their discovery of the cove. 13 April 1773". A view on Motuara Island is where "Capt Furneaux in April 1773 made a garden on this island and also put up tents and landed men sick with scurvy". Duncan comments on the accuracy of historic descriptions of the landscape, thereby adding to the historical record. Alongside a photograph of The Hole in the Wall on the Eastern Cape, for example, he states that he "measured the arch roughly, and found that the length and breadth as given on p. 192 of Banks' journal are practically correct. I could not measure the height, but I think that Banks' estimate is too high". He relishes too in noticing how the ghostly remnants of Captain Cook's presence are still imprinted in the landscape, thereby blurring past and present. He points out that the tree stumps seen at Observation Point are the result of "a good sized clearing... made for astronomical work. Small shrub has now grown but some stump of trees that were cut down remain" as well as excitedly noting "a place... where all large stones had been moved to make a clear room for launching a boat" that, combined with the finding of "a long platform of punga trees.... piles of lead and bits of charcoal" most likely indicated "the place where the long-boat of the 'Endeavour' was... made ready for sea in 1795" (Figs. 6 and 7).

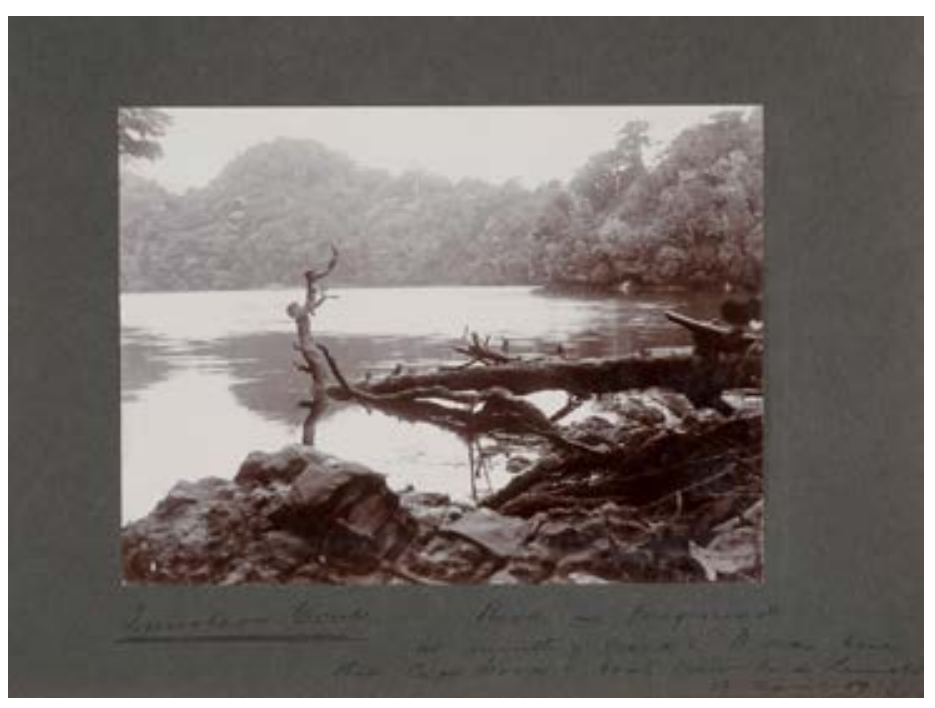

Figure 5. Russell Duncan, Luncheon Cove, circa 1905-1910, photograph (albumen print) Auckland Art Gallery Toi o Tãmaki, purchased 1988. 

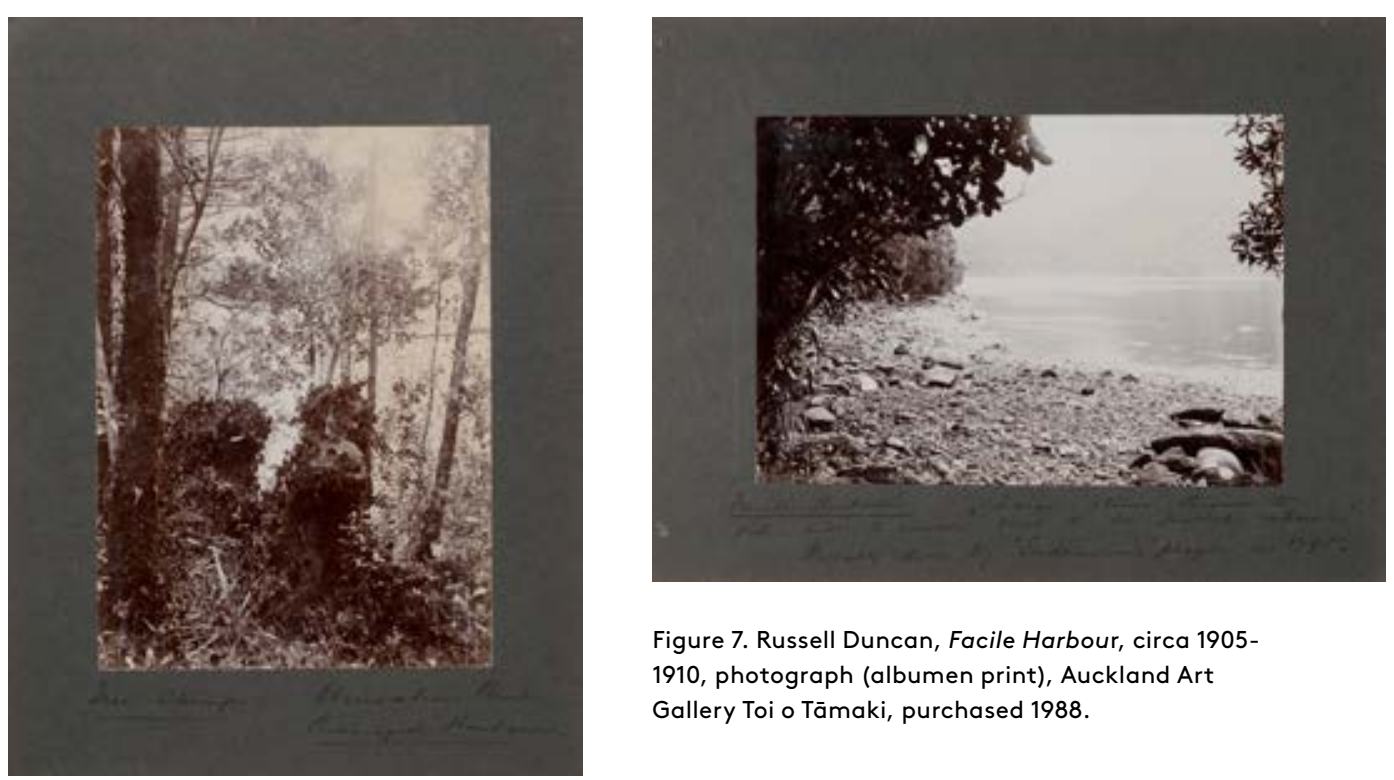

Figure 7. Russell Duncan, Facile Harbour, circa 19051910, photograph (albumen print), Auckland Art Gallery Toi o Tämaki, purchased 1988.

Figure 6. Russell Duncan, Tree stumps,

Observation Point, Pickersgill Harbour, circa 1905

1910, photograph (albumen print), Auckland Art

Gallery Toi o Tāmaki, purchased 1988

It is clear from these inscriptions that Duncan's view of the depicted landscape is shaped by a specifically colonial historic viewpoint that is centred on Captain Cook; all else is auxiliary detail. This in turn directs the viewer's reading of the photographed geography: we read and understand the photographs through the information provided in the inscriptions, which narrate a selected history. Yet as noted, the inscriptions do not simply describe Captain Cook's voyages but also Duncan's process of re-tracing. The inscriptions thus create and suggest multiple layers of time - Captain Cook's voyages, Duncan's excursions, the time between those journeys and our reading-further complicating the here-now and the there-then suggested by the photographs.

Duncan's date inscriptions explicitly create, harness, and call attention to this temporal tension. They make evident that Duncan has arranged his photographs of the sites by the order in which Captain Cook visited them, and not in the order in which he took the photographs at the specific locations. View towards water at Anchor Point, taken 16th January 1910, documents the first anchorage of the Resolution on 26th March 1773 (Fig.8). Next to this photograph, is View of Pickersgill Harbour (Fig. 9) taken three days prior on 13th January
1910, where "Captain Cook brought Resolution through the passage in centre of view 27 March 1773". Following this is Pickersgill Harbour (Fig. 10), also taken 13 January 1910, which depicts where "Resolution moved where the two boats are 'so near to the shore as to reach in with a Brow or stage."' The sequential order of the photographs first and foremost charts Captain Cook's movements through the landscape, enabling the viewer to retrace his historic footsteps.

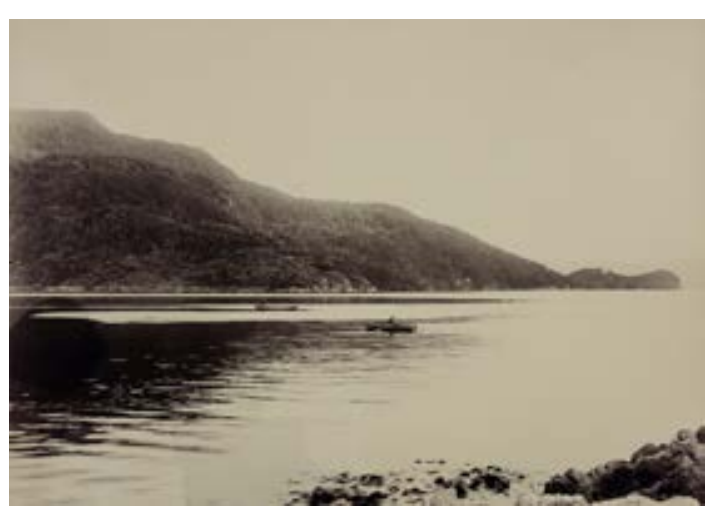

Figure 8. Russell Duncan [View towards water at Auncan Collection, Duncan Collection, Alexander Turnbull Library, PA1-0-137-21.

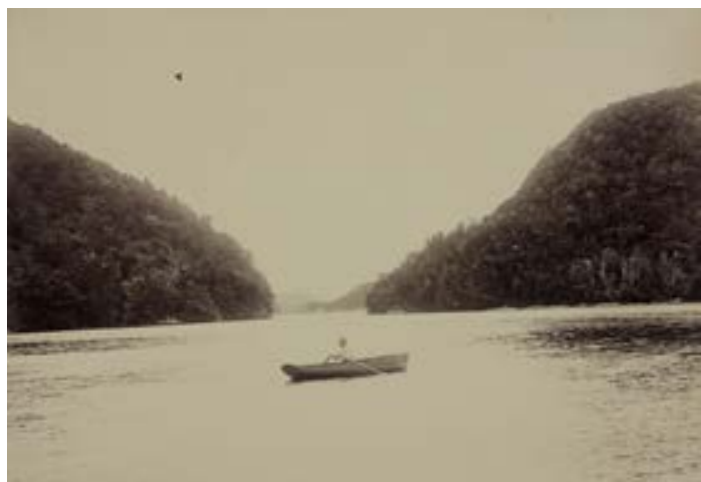

Figure 9. Russell Duncan [View of Pickersgill Habour, water, man], Alexander Turnbull Library, PA1-0-137-22

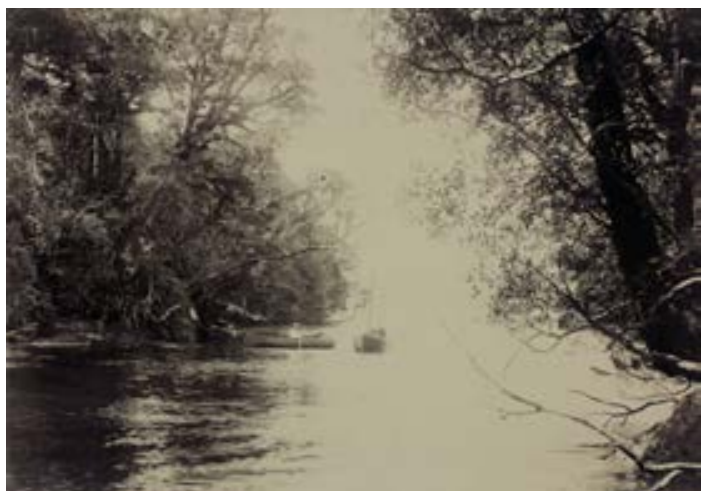

Figure 10. Russell Duncan [View from wooded cove in Pickersgill], Russ Duncan Collection, Alexander Turnbull Library, PA1-0-137-23. 


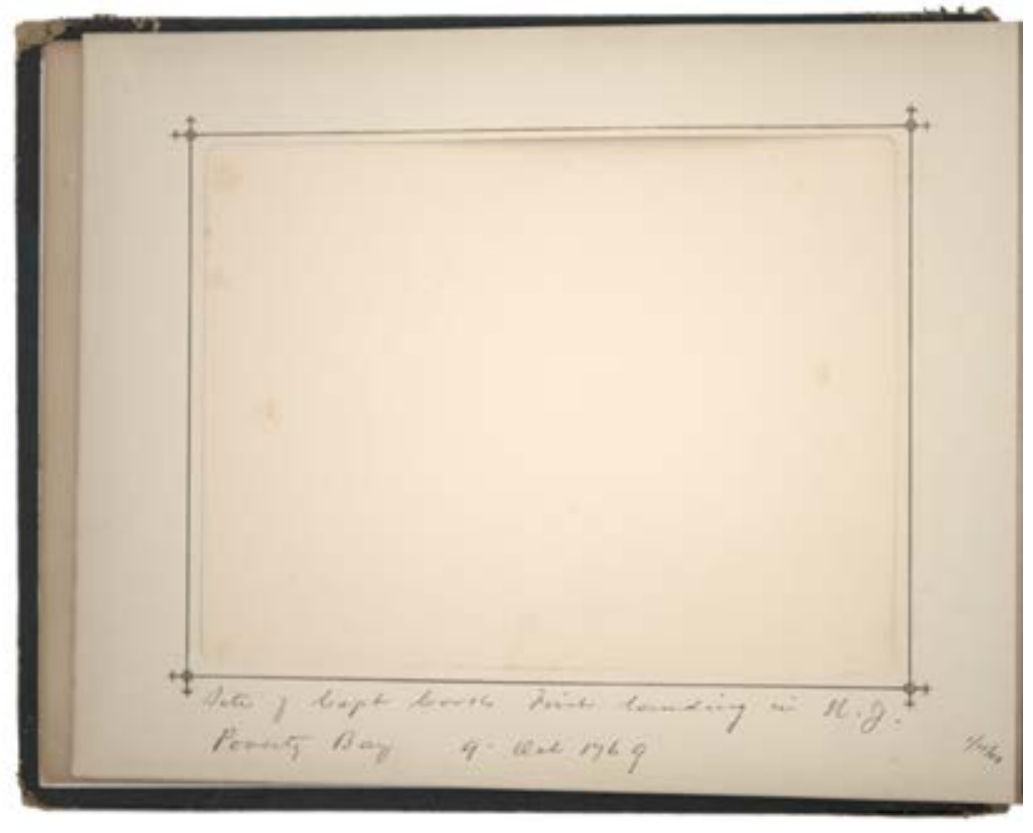

Duncan's ordering of the albums was considered, laboured and varied. While there are some overarching alignments in the photographic sequences of the voyages across the public institutions, there are also instances of additions, subtractions, and re-shufflings. In several of his albums it is clear that he re-ordered individual photographs across and within albums to alter pre-existing sequences: in Volume 2 in the Auckland War Memorial Museum Tāmaki Paenga Hira's collection, for example, there are two or more pencilled numbers written in Duncan's hand on the verso of the photographs that suggest that an alternative sequence had been considered. In several instances there are some photographs missing from the album sequences: their absence indicated by a blank inset; their intended presence indicated by detailed place and date inscriptions (Fig. 11). These inscriptions and these absences evocatively complicate Duncan's construction of time by simultaneously suggesting and evading an alternative reading and timeline that was intended but never eventuated. This in turn highlights the constructedness of the narrative we see in front of us: the positioning of the photographs was not by chance, but rather a deliberate exercise executed over a period of time.
The photographs' visual features are integral to the realization of the experiential journey Duncan envisaged and deliberately planned. Presented in a sequence, the photographs provide different viewpoints of the described sites, often fluctuating from a distanced, elevated perspective to a lower, closer viewpoint. In addition to creating a sense of movement through the landscape, these shifting perspectives also create complex positionings (both spatial and temporal) for how the viewer experiences this visual journey. In View towards water at Anchor Point (Fig.8) we view from a distance a boat located on the site of the anchorage of the Resolution, prompting us to imagine the ship's ghostly presence in front of us. In View of Pickersgill Harbour (Fig. 9) we shift to view the site as it would have been seen by Cook and his associates from inside the boat, looking out towards the passage through which they would later traverse. Then again we shift to the position of bystander in Pickersgill Harbour (Fig. 10); positioned on the shore, we are prompted to imagine ourselves reaching for the 'brow or stage' described by Cook. The inclusion of Duncan's travelling companions in these photographs further blurs the relationship between the past and present by creating echoes of encounter that are layered across the landscape.

Duncan seems to employ this technique to maximise narrative suspense in his organisation of the photographs of Grass Cove. In the first image of the sequence we see a man in a boat, accompanied by the inscription "When Burney was searching for the lost boat + crew belonging to the 'Adventure' it was here that he found a canoe" [which contained some of the crew's possessions] (Fig. 12). The next photograph provides a more elevated, lateral view of the cove, "west from" the previous image (Fig. 13). Then, we are placed on the cove itself, the "scene of massacre of Mr. Rowe, Mr Woodhouse and 8 members of the crew of Adventure - 17th Dec 1773" (Fig. 14). Duncan builds a sense of anticipation, re-creating Burney's growing sense of dread as to what he would find at the cove.

Duncan's photographs were, on at least two occasions, incorporated within other historians' chronicles, adding further layers to the meanings and temporal significances embedded in the photographs. In both occasions, the photographs were intended to 'illustrate' historical events associated with specific sites. The writer Edith Howes (1872-1954) includes one of Duncan's photographs of Grass Cove in her travel guide Marlborough Sounds: The Waters of Restfulness (1918) to illustrate her description of the site's historic significance - i.e. the murder of Cook's crew in 1773. 


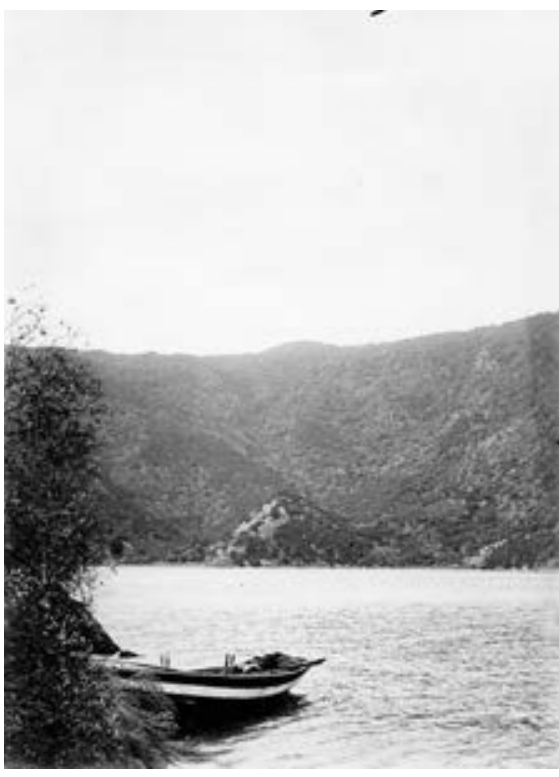

Figure 12. Russell Duncan (b.1855, d.1946), Wharehunga Bay, Queen Charlotte Sound 31 Mar 1902, gifted by Jasper Herrick, Collection of Hawke's Bay Museums Trust Ruawharo Tâ-ū-rangi, 15757.

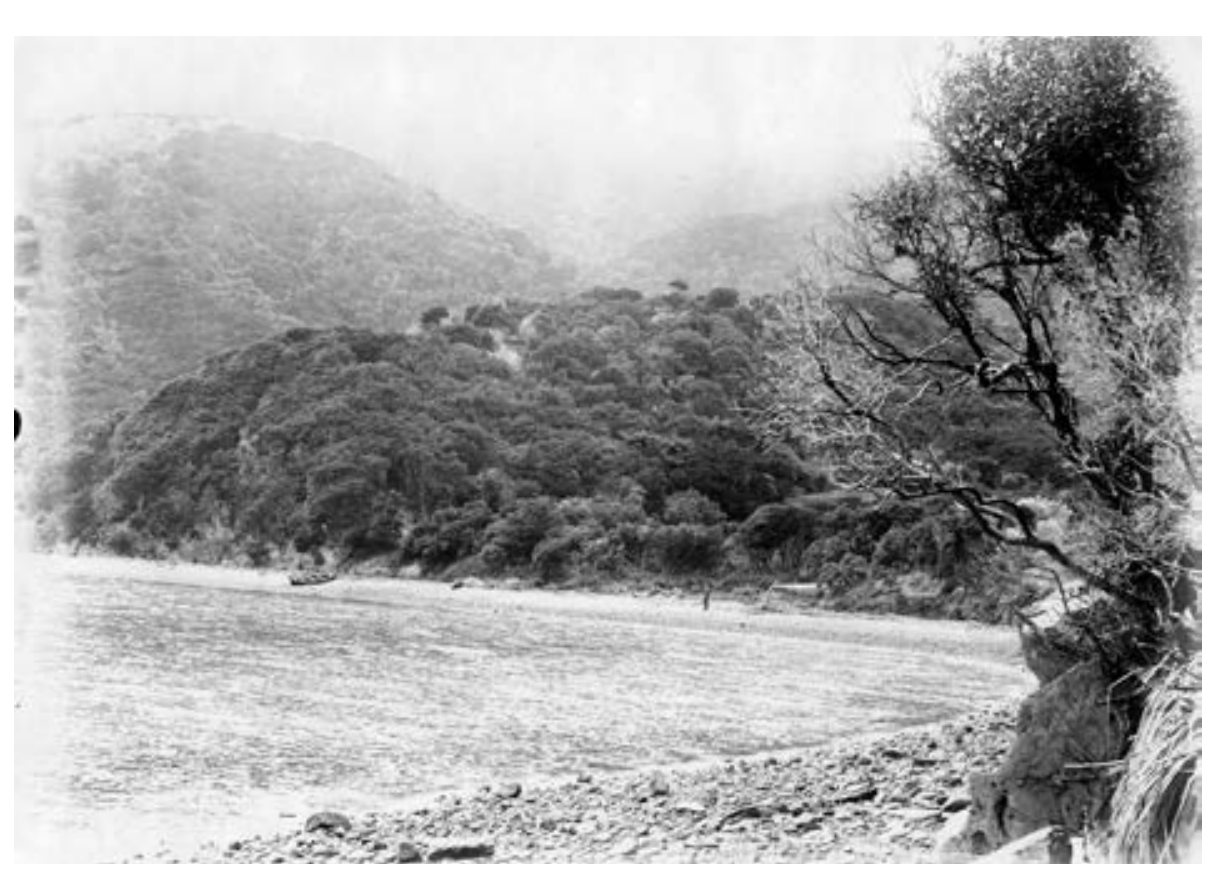

Figure 14. Russell Duncan (b.1855, d.1946), Wharehunga Bay, Queen Charlotte Sound, 31 Mar 1902 gifted by Jasper Herrick, Collection of Hawke's Bay Museums Trust, Ruawharo Tā-ū-rangi, 15759.

Figure 13. Russell Duncan (b.1855, d.1946), Wharehunga Bay, Queen Charlotte Sound, 31 Mar 1902, gifted by Jasper Herrick, Collection of Hawke's Bay Museums Trust, Ruawharo Tā-ū-rangi, 15758.

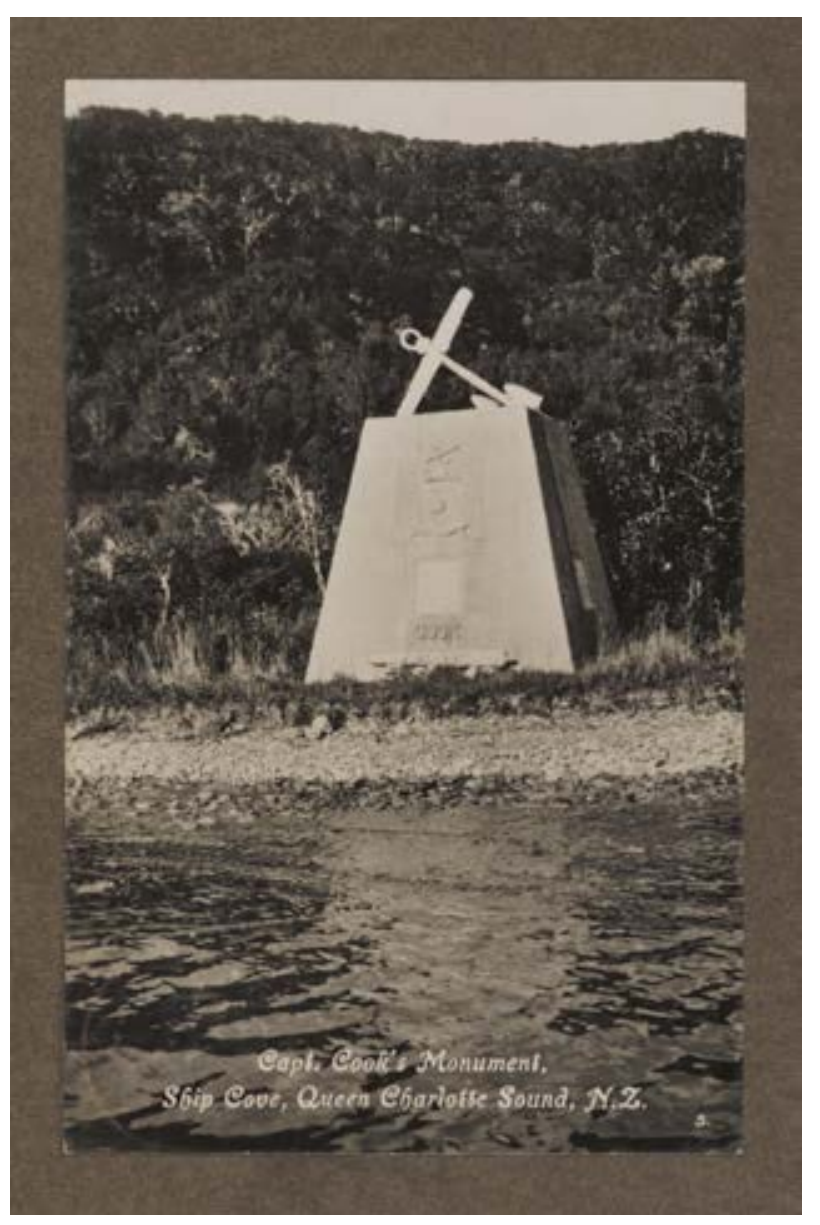

Figure 15. Unknown. Ship Cove, from "Places visited by Captain Cook. 2,"Russell Duncan, 1902-1928, Auckland War Memorial Museum, PH-ALB-402-2.
An album compiled by the clerk and historian Johannes Carl Anderson (1873-1962) in the Auckland War Memorial Museum Tāmaki Paenga Hira's collection intersperses Russell Duncan's photographs with portraits of Captain Cook and Joseph Banks. ${ }^{28}$ These are accompanied by images of Captain Cook monuments erected in Ship Cove (1918) (Fig. 15), a newspaper article about Russell Duncan's lecture in 1902, and an advert for a lecture delivered by Hon. R. McNab to fundraise for the Captain Cook Memorial Fund. In this environment, Duncan's photographs and Duncan himself become incorporated within an argument that harnesses and celebrates historicity to advocate for a certain cause: namely, the elevation of Cook as a national symbol for the burgeoning colony. These examples indicate that Duncan's photographs were viewed by his own peers as being first and foremost 
illustrations of historical sites and events, rather than documentation of his own journeys. The photographs had, from the outset of their production and reception, assumed a complex temporal reading and significance that extended beyond the confines of the photographic image to suggest that which cannot be seen: history. Duncan's photographic responses to and interpretation of historical events had, within his own context, become entrenched as historical record itself.

Duncan's construction of time in his photographic sequences of Cook's sites was a response to, and an extension of, the nationalising agenda of his colonial environment. ${ }^{29}$ The date stamps, written inscriptions, and visual narratives serve to entrench Cook's presence in the landscape by fostering experiential re-tracings of the voyager's steps. In light of the upcoming anniversary, Tuia Encounters 250, it is pertinent to analyse how Duncan's photographic practice heroised Captain Cook, both in its production and in its subsequent reception, as well as considering the implications of this legacy. As part of the 'national commemoration' of Captain Cook's landing at Aotearoa New Zealand, a flotilla including a replica of the Endeavour will travel to four of the main Cook landing sites, an expedition not dissimilar from those undertaken by Duncan and his peers. Such plans demonstrate the enduring elevated status that Cook occupies as a symbol of national historical identity in contemporary Aotearoa New Zealand. This is not, of course, without its complications and tensions. Cook's landing precipitated a swathe of violations inflicted against Māori, both as part of his voyages and later as part of the British colonisation project. These violations, both in their substance and in the historical trauma they inflicted, continue to reverberate today. ${ }^{30}$ Cook, for many, is a symbol of oppression, injustice, and pain.

What can we then, as a viewer in twenty-first century Aotearoa New Zealand, bring to the reading of Duncan's photographs of Cook's sites? With each sighting of Duncan's photographs the 'pasts' of the historic voyages and Duncan's expeditions are constantly re-iterated, re-layered and re-enacted, repopulating the depicted landscapes with a selected Euro-centric narrative. The here-now (Duncan's gaze) and the there-then (Cook's journey) continuously blend and fissure, creating ambiguous timelines that the viewer, experiencing it all simultaneously in the 'present', further complicates. What, then, can we carry with us on this conceptual journey? How can we traverse Duncan's herenow and there-then meaningfully? Certainly we need to be armed with the awareness that Duncan's photographs arose out of a specific socio-historical context in which the historical memory of Cook was harnessed in the formation of a colonial identity that ultimately prioritised Pākeha relationships to land. Indeed, Duncan makes very little mention of Māori in his inscriptions; when he does, they feature as characters in Cook's narrative rather than occupying an autonomous existence. We must therefore approach Duncan's photographs empowered with the awareness that they do not simply record but rather select and construct a narrative with a specific agenda. We need to proactively work with the layers of time constructed in his photographs to meaningfully impart new readings and narrative into what Duncan's there-then constitutes for our here-now, with knowledge of the unseen people and absent events in Duncan's photographic vision of history.

\section{REFERENCES}

Barthes, Roland. Camera Lucida: Reflections on Photography, trans. Richard Howard. New York: Hill and Wang, 1981.

Conceição, N. R "Sparks of reality: on the temporalities of the photographic image." Aisthesis 11, no. 2 (2018): 179-188.

Gentry, Kynan. History, heritage and colonialism: Historical consciousness, Britishness, and cultural identity in New Zealand, 1870-1940. Manchester: Manchester University Press, 2015.

Wevers, Lydia. Country of Writing: Travel Writing and New Zealand 1809-1900. Auckland: Auckland University Press, 2002.

Whybrew, Christine Mary. "The Burton Brothers Studio: Commerce in Photography and the

Marketing of New Zealand, 1866-1898."PhD diss. University of Otago, 2010

Auckland Star, "Ascent of Ruapehu," 25 Jan 1898.

New Zealand Herald, "Ascent of Tongariro and Ngaurohoe," 15 Jan 1898.
Otago Daily Times, "Dusky Sound Exploration," 7 Feb 1910.

Otago Daily Times, "New Zealand Literature," 24 May 1930.

Wanganui Chronicle, "Rival Discoveries," 28 Ju 1910

Duncan, Russell. "Following the Tracks of Captai Cook." Art. IV, read before the Hawke's Bay Philosophical Institute, 1st December 1902.

Duncan, Russell. “Journal on Dusky Sound," 1910. MTG Hawkes Bay, 091 Dun, no: 1867.

Duncan, Russell. "Some early history," transcript of radio interview, 16 August 1935. MTG Hawkes Bay.

Duncan, Russell. "Some early history," transcript of radio interview, 7 September 1935. MTG Hawkes Bay.

Two Rooms. "Views from Astronomer's Point" https://tworooms.co.nz/exhibition/viewsastronomers-point/. 


\section{END NOTES}

1 MTG Hawkes Bay M96/6/1, 1, 68209.

2 See Kynan Gentry, History, heritage and colonialism: Historical consciousness, Britishness, and cultural identity in New Zealand, 1870-1940 (Manchester: Manchester University Press, 2015), p. 141.

3 See website description for Adams' exhibition "Views from Astronomer's Point" at Two Rooms, Auckland (2 June - 8 July 2017): https://tworooms.co.nz/exhibition/viewsastronomers-point/. Adams states: "in the late nineteenth century Russell Duncan, a photographer and Robert $\mathrm{McNab}$, historian and parliamentarian, visited the Dusky Sound sites associated with the 1773 voyage of James Cook. When I was twelve I was given a children's book about Cook's voyages to the Pacific, illustrated by Duncan's photographs. My photographs are 'after' the paintings and photographs of Cook's artist William Hodges and Duncan. Their origin is a childhood dream prompted by the misrecognition of a Duncan photograph of blurry forms shrouding Totara stumps and Kidney Ferns that grew into monsters. I knew I had to go there." It should be noted here that I have found no reference or record of the book that Adams describes. describes.

4 MTG Hawkes Bay M96/6-3 [20114].

5 MTG Hawkes Bay M96/6-9[20110].

6 New Zealand Herald, "Ascent of Tongariro and Ngaurohoe," 15 Jan 1898: 5.

7 Auckland Star, "Ascent of Ruapehu," 25 Jan 1898: 5.

8 Lydia Wevers, Country of Writing: Trave Writing and New Zealand 1809-1900 (Auckland: Auckland University Press, 2002) p. 184

9 Christine Mary Whybrew, "The Burton Brothers Studio: Commerce in Photography and the Marketing of New Zealand, 1866898" (PhD diss., University of Otago, 2010) p. 104.

10 Ibid., p. 110.

11 MTG Hawkes Bay M96/6-3 [20114]

12 MTG Hawkes Bay, Album No 10

13 Roland Barthes, Camera Lucida: Reflections on Photography, trans. Richard Howard (New York: Hill and Wang, 1981), p. 79.

14 See N. R. Conceição, "Sparks of reality: on the temporalities of the photographic image," Aisthesis 11, no. 2 (2018): 186.
15 Ibid.

16 Otago Daily Times, "Dusky Sound Exploration," 7 Feb 1910

17 See diary entries for Wednesday 26 January 1910 and Saturday 29 January 1910 written in Russell Duncan, "Journal on Dusky Sound,"

1910, MTG Hawkes Bay, 091 Dun, no: 1867.

18 Russell Duncan, "Following the Tracks of Captain Cook," Art. IV, read before the Hawke's Bay Philosophical Institute, 1st December 1902, p. 44. The site was initially rediscovered by A. H Turnbull in 1901, howev was not plotted nor documented other than by a personal photograph. Turnbull's photograph of the location assisted Duncan's confirmation of the location.

19 See Duncan, "Following the Tracks of

Captain Cook"; the transcripts for the radio interviews, entitled "Some Early History" can be accessed in the MTG Hawkes Bay collection.

20 Duncan, "Following the Tracks of Captain Cook," p. 44.

21 Ibid., p.35.

22 Ibid., p. 32

23 Otago Daily Times, "New Zealand Literature," 24 May 1930.

24 For a more detailed discussion, se Gentry, History, heritage and colonialism Historical consciousness, Britishness, and cultural identity in New Zealand, 1870-1940 (Manchester: Manchester University Press, 2015).

25 Ibid., p. 141.

26 Ibid., p. 142.

27 Ibid., p. 142. McNab and Duncan's shared interest in Cook resulted in a competitive relationship. The two were embroiled in a public argument in which McNab's claim of being the first to identify the site of the massacre at Grass Cove were strongly disputed by Duncan. See Wanganui Chronicle, "Rival Discoveries," 28 Jul 1910, p. 5.

28 Auckland War Memorial Museum Tāmaki Paenga Hira, [PH-ALB-402-1].

29 Although it is out of the scope of this article to analyse in much detail, it is important to note that this agenda is also evident in Duncan's photographic albums focusing on sites associated with the New Zealand Land Wars. The albums generally focus on the various locales' significance for Pākehā history and neglect the atrocities suffered by Māori. 30 "Movement to boycott this year's 250th anniversary of Captain James Cook's landing gains strength," https://www.tvnz.co.nz/onenews/new-zealand/movement-boycott-years250th-anniversary-captain-james-cooks-

landing-gains-strength 